\title{
海綿静脈洞部巨大動脈瘤の外科治療
}

\author{
伊達 勲，浅利 正二，大本 堯史
}

\section{Surgical Treatment of Intracavernous Giant Aneurysms}

\author{
Isao Date, M.D., Shoji Asari, M.D., and Takashi Ohmoto, M.D. \\ Department of Neurological Surgery, Okayama University Medical School, Okayama, Japan
}

\begin{abstract}
Summary: We present 24 cases of intracavernous giant aneurysms which we have treated so far. All the cases were unruptured and showed neurological signs such as ocular movement disorder and visual dysfunction. There were 11 males and 13 females and the age of the patients ranged between 11 and 75 years (mean 51 years). The follow-up periods were between 6 months and 19 years (mean 6.7 years). Among the cranial nerves, the abducens nerve was affected in 17 cases, oculomotor nerve in 11 cases, optic nerve in 6 cases, trigeminal nerve in 5 cases and trochlear nerve in 4 cases. In addition to conventional angiography, balloon test occlusion (BTO), slow injection angiography, aneurysmography and SPECT with BTO were used to determine a method of treatment. Treatment options were as follows; nonsurgical treatment in 4 cases, common carotid artery ligation (CC ligation) in 7 cases, internal carotid artery ligation (IC ligation) in 2 cases, STA$\mathrm{MCA}$ anastomosis with IC ligation or IC trapping in 6 cases, high flow vein bypass with IC ligation in 3 cases and direct clipping in 2 cases. Although only 2 cases showed early and late ischemic complications, other cases demonstrated improvement of cranial nerve dysfunction relatively soon after treatment and long-term prognoses were good. We conclude that selecting an adequate surgical treatment by using sophisticated diagnostic methods plays an important role for obtaining good outcome for intracavernous giant aneurysms.
\end{abstract}

\author{
Key words: \\ - intracavernous \\ aneurysm \\ - giant aneurysm \\ - surgery
}

Surg Cereb Stroke (Jpn) 25: 140-147, 1997

\section{はじめに}

内頸動脈海綿静脈洞部の巨大動脈瘤に対しては，以前か ら頸部での内頸動脈あるいは総頸動脈の結紮術が主として 行われてきた6) 20) 26). 最近になって，血管内手術の発達に より術前にballoon test occlusion (BTO) などを用いた脳血 流予備能の評価が可能になったこと, 微小解剖あるいはマ イクロサージャリーの技術の発達などにより，種々のバイ パス術を併用した結紮術や，直達手術も行われるようにな
ってきている1－4）7）8１0）25）。我々はこれまでに，同部位 の巨大動脈瘤 24 例を経験し, 種々のアプローチでこれら を治療し，良好な成績をあげてきた。本稿では，これら 24 例を治療法ごとに検討し, その治療成績を述べるとと もに，現時点での同部位の巨大動脈瘤に対する治療方針に ついて考察する.

対象および方法

1971年から 1995年の間に我々の経験した内頸動脈海綿 
静脈洞部の巨大動脈瘤(最大径 $2.5 \mathrm{~cm}$ 以上) は 24 例であっ た. 全例が眼球運動障害, 視力視野障害などの神経症状を 呈した症候性動脈瘤であり，未破裂であった。性別は男性 11 例, 女性 13 例であり, 年齢は 11 歳から 75 歳 (平均 51 歳), 追跡期間は 6 力月から 19 年(平均 6.7 年)であった.

前述のように全例が症候性動脈瘤であったが，障害され ていた脳神経は, 外転神経が最も多く 17 例, ついで動眼 神経が 11 例, 視神経が 6 例, 三叉神経が 5 例, 滑車神経 が4例であった。

治療法を決定するにあたって, 術前に施行した検査は, 通常の脳血管撮影に加えて, 最近の症例では30分のballoon test occlusion (BTO), BTO下での slow injection angiographyおよび aneurysmography, BTO下でのSPECT などである。これに加えて, 患者の年齢, 他疾患の有無な どを参考に治療法を決定した。現時点での我々の治療法の 選択基準を Fig. 4 に示すが，かなり以前の症例では一部の 検査は施行しえなかったため, 通常の血管撮影に加えて, 用手マタステストでの神経症状の変化などを参考に治療法 を決定した。
その結果，手術を行わなかったものは 4 例で，治療法の 内訳は, 総頸動脈の結紮のみを行ったもの 7 例, 内頸動脈 の結紮のみを行ったもの 2 例, 内頸動脈結紮ないしトラッ ピングに浅側頭動脈一中大脳動脈吻合術 (STA-MCA anastomosis)を加えたもの6例, 内頸動脈結紮に high flow vein bypassを加えたもの 3 例, 直接クリッピング術を施行し たもの 2 例であった.

\section{結果}

\section{全24症例のまとめをTable 1 に示す.}

症例 1 から 4 までは非手術例であるが，その理由は高齢， 他疾患の合併および患者側の手術拒否であった４年から 10 年経過観察しているが, 動脈瘤の大きさ, 神経症状と も変化のあった例はみられなかった。

症例 5 から 13 までは, 総頸動脈ないし内頸動脈の結紮術 のみを施行した症例である。症例 9 を除いて結紮術後神経 症状の改善が見られており, 長期予後も良好であった。症 例 11 では, 総頸動脈結紮術後神経症状の改善がみられ, 正常な社会生活をおくっていたが, 結紮術 5 年後に遊離血

Table 1 Summary of the 24 cases of intracavernous giant aneurysms

\begin{tabular}{|c|c|c|c|c|c|c|}
\hline $\begin{array}{l}\text { Age } \\
\text { Sex }\end{array}$ & $\begin{array}{l}\text { Cranial nerve } \\
\text { involvement }\end{array}$ & $\begin{array}{l}\text { Size } \\
(\mathrm{mm})\end{array}$ & Treatment & $\begin{array}{l}\text { Follow-up } \\
\text { period (year) }\end{array}$ & $\begin{array}{l}\text { Improved } \\
\text { cranial nerves }\end{array}$ & Outcome \\
\hline 1. $51 \mathrm{~F}$ & III & 32 & No & 10 & & no change \\
\hline 2. $72 \mathrm{~F}$ & III & 29 & No & 8 & & no change \\
\hline 3. $74 \mathrm{M}$ & II , III & 25 & No & 4 & & no change \\
\hline 4. $53 \mathrm{~F}$ & III, V, VI & 25 & No & 5 & & no change \\
\hline 5. $60 \mathrm{~F}$ & III, IV, V, VI & 33 & CC ligation & 19 & $\mathrm{~V}$ & good \\
\hline 6. $48 \mathrm{M}$ & $\mathrm{II}, \mathrm{VI}$ & 25 & CC ligation & 21 & VI & good \\
\hline 7. $50 \mathrm{~F}$ & III, IV, V, VI & 30 & CC ligation & 14 & III, IV, V, VI & good \\
\hline 8. $61 \mathrm{~F}$ & III, V & 30 & CC ligation & 12 & $\mathrm{~V}$ & good \\
\hline 9. $11 \mathrm{M}$ & II & 32 & CC ligation & 18 & & good \\
\hline 10. $53 \mathrm{M}$ & II , III, IV, V, VI & 35 & CC ligation & 13 & II, III, IV, V, VI & good \\
\hline 11. $55 \mathrm{M}$ & VI & 32 & CC ligation & 5 & VI & died 5 years later \\
\hline 12. $64 \mathrm{~F}$ & II, III, VI & 35 & IC ligation & 10 & II, III, VI & good \\
\hline 13. $75 \mathrm{~F}$ & III, VI & 30 & IC ligation & 10 & III, VI & good \\
\hline 14. $61 \mathrm{M}$ & IV & 25 & IC lig. + STA-MCA & 10 & IV & good \\
\hline 15. $56 \mathrm{M}$ & III, VI & 32 & IC lig. + STA-MCA & 2 & III, VI & good \\
\hline 16. $40 \mathrm{M}$ & II , VI & 25 & IC lig. + STA-MCA & 1 & II, VI & good \\
\hline 17. $22 \mathrm{M}$ & thalamic infarct & 30 & IC lig. + high flow & 2 & & good \\
\hline 18. $34 \mathrm{M}$ & $\mathrm{VI}$ & 32 & IC lig. + high flow & 2 & VI & good \\
\hline 19. $23 \mathrm{M}$ & $\mathrm{VI}$ & 28 & IC lig. + high flow & 0.5 & VI & good \\
\hline 20. $65 \mathrm{~F}$ & $\mathrm{VI}$ & 35 & IC trap. + STA-MCA & 2 & VI & good \\
\hline 21. $46 \mathrm{~F}$ & $\mathrm{VI}$ & 28 & IC trap. + STA-MCA & 2 & VI & good \\
\hline 22. $50 \mathrm{~F}$ & VI & 30 & IC trap. + STA-MCA & 1 & & fair \\
\hline 23. $56 \mathrm{~F}$ & $\mathrm{VI}$ & 32 & Direct clipping & 3 & VI & good \\
\hline 24. $52 \mathrm{~F}$ & $\mathrm{VI}$ & 28 & Direct clipping & 2 & VI & good \\
\hline
\end{tabular}

CC ligation: common carotid artery ligation, IC ligation: internal carotid artery ligation, lig.: ligation, STA-MCA: superficial temporal artery-middle cerebral artery anastomosis, high flow: high flow bypass using EC (external carotid)-M2 saphenous vein graft, IC trap.: Internal carotid artery 

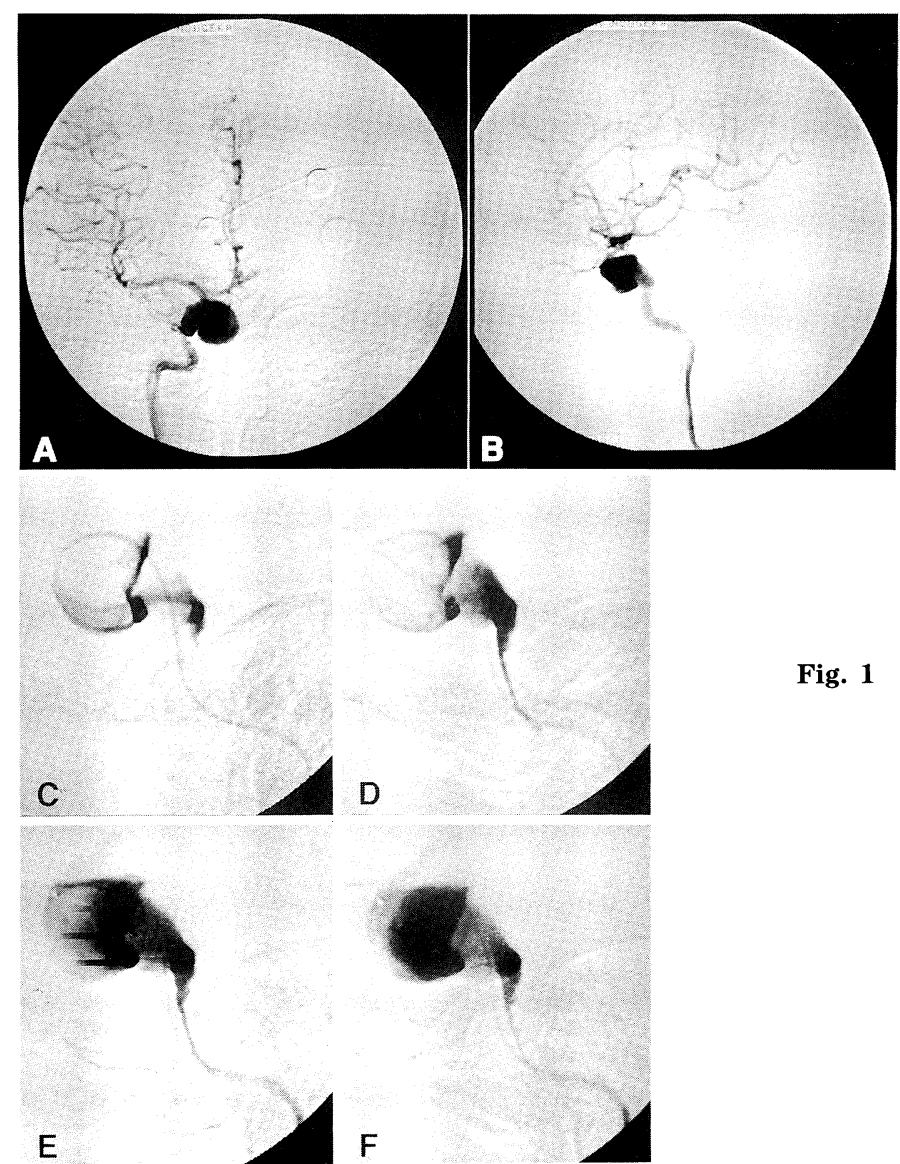

Fig. 1 Case 16, 40 year-old male with progressive right visual disturbance and right abducens palsy. A, B: Conventional digital subtraction angiography shows an intracavernous giant aneurysm $25 \mathrm{~mm}$ in size. $\mathbf{C}-\mathbf{F}$ : Aneurysmography is useful for delineating the exact position of the neck and dome of the aneurysm. G: SPECT with balloon test occlusion shows apparent decrease of cerebral blood flow reserve in the right hemisphere. H: Postoperative angiogram (lateral view) demonstrates the patent STA-MCA anastomosis.

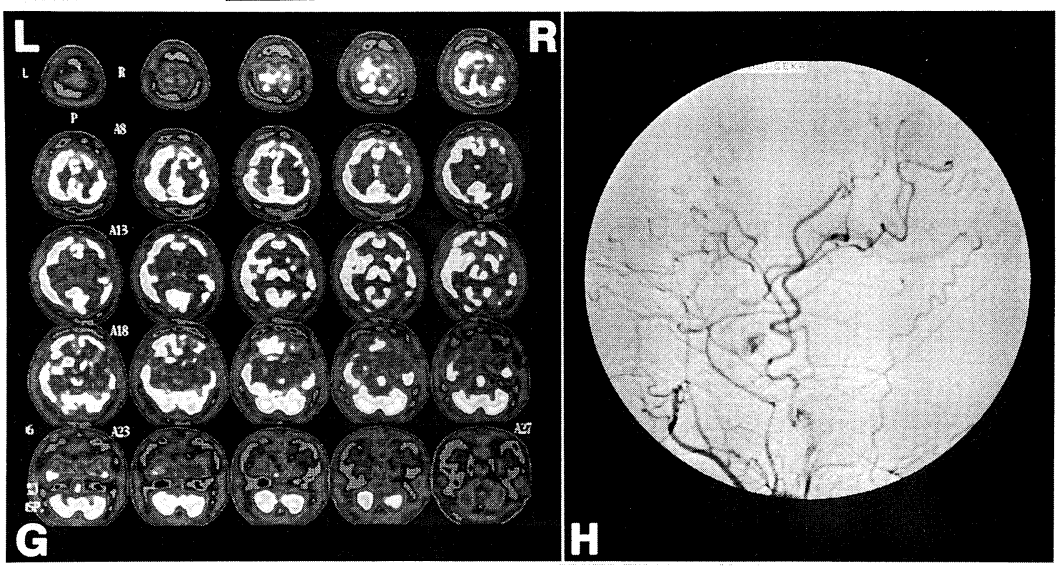

栓によると思われる脳塞栓を発症し死亡している。その他 の症例で術後脳虚血によると思われる症状を呈したものは なかった。

症例 14 から 22 までは，内頸動脈結紮術に加えてバイパ ス手術を施行した症例である。症例 14 から 16 ではバイパ ス手術としてSTA-MCA anastomosisを，症例 17 から 19 はバイパス手術として伏在静脈を用いた EC (外頸動脈) M2 high flow bypassを施行した。また，症例 20 から 22 ま
では，直接クリッピング術を試みたが結局完遂できず，内 頸動脈トラッピング術(頸部内頸動脈と動脈瘤のすぐ遠位 部でトラッピング)とSTA-MCA anastomosisを施行した 症例である。症例 17 は同側の小さな視床梗塞で発症した 症例で，眼球運動障害は認められなかった。その他の症例 では症例 22 を除いて術後神経症状の改善がみられており, 経過良好であった。症例 22 は，直接クリッピングを施行 しょうとして内頸動脈の遮断時間が長くなりすぎ，同側 


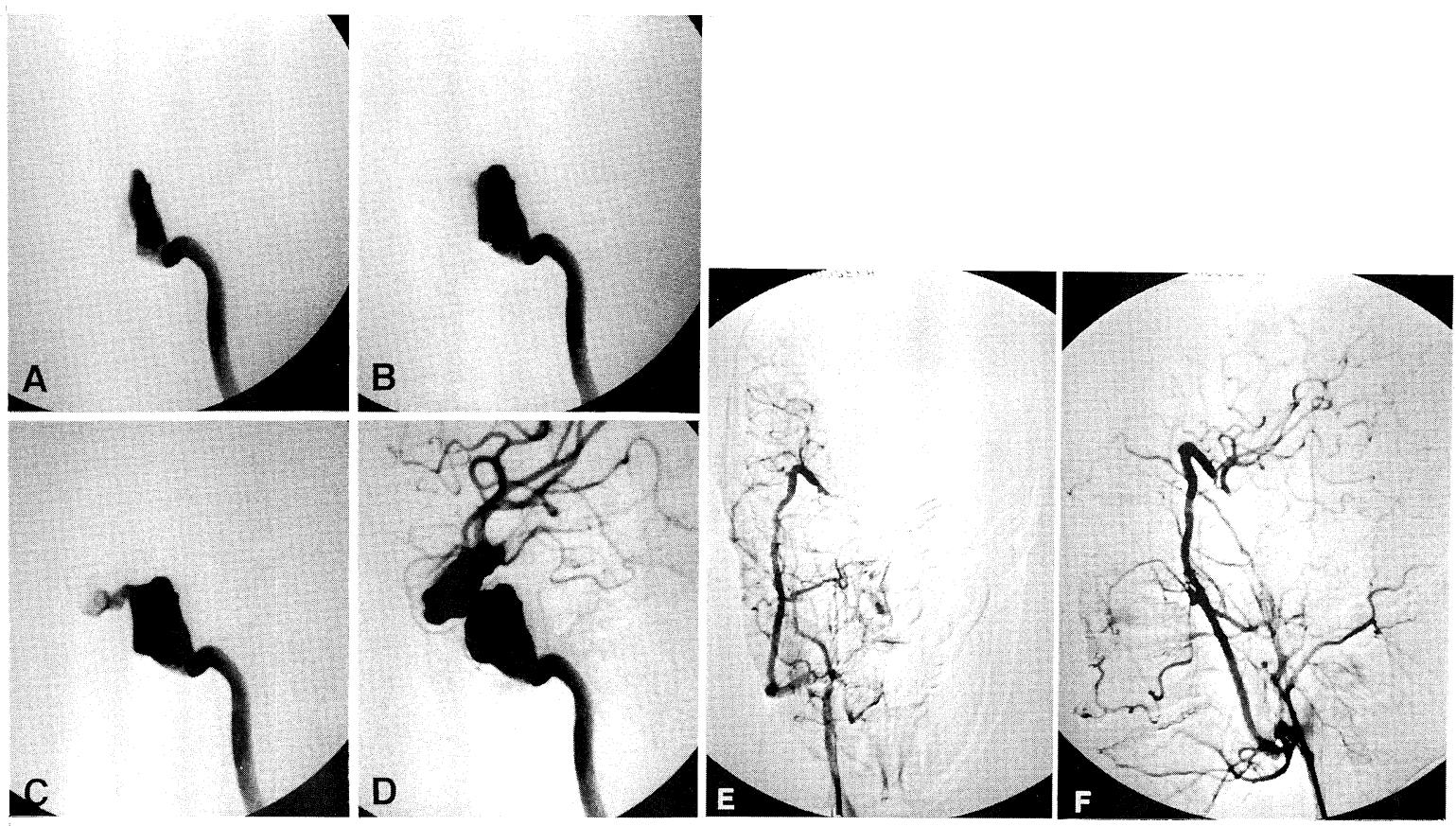

Fig. 2 Case 17, 22 year-old male with right small thalamic infarction. A - D: Slow injection angiography is useful for showing the exact position of the irregular-shaped giant aneurysm in the $\mathrm{C} 3$ and $\mathrm{C} 4$ portion. E, F: Postoperative angiogram demonstrates the patent EC-M2 high flow bypass.

（右)の中大脳動脈領域に梗塞を生じ，不全片麻痺を残して いる.

症例 23 掞よび 24 は直接クリッピング術を施行した症例 である。いずれも anterior siphon (C3)部に動脈瘤の neck があり, trapping-evacuation法 ${ }^{27)}$ を併用して動脈瘤の減 圧をはかりながら動脈瘤壁を開放し，動脈瘤内面と外面か ら orificeを確認したうえでクリッピングを施行した。両 症例とも術前見られていた外転神経麻瘦は消失し, 良好な 経過をたどっている.

代表的な症例を呈示する。

<症例 16> 40歳, 男性.

数力月の経過で進行した右視力低下および右外転神経麻 瘦を主訴として入院し, 脳血管撮影にて海綿静脈洞部に $25 \mathrm{~mm}$ 径の巨大動脈瘤を認めた(Fig. 1A，B). 右内頸動脈 のC6部にballoonを留置し, balloon inflation 下にマイク ロカテーテルを動脈瘤内に誘導し，動脈瘤を撮影した (aneurysmography).この方法により動脈瘤の neckがC4 部にあることが確認された(Fig. 1C-F)。本症例では，BTO 時に神経脱落症状は認められなかったが, BTO下で施行 したSPECTにて明らかな右大脳半球の血流低下が認めら れたので (Fig. 1G), 右STA-MCA anastomosis と右内頸動 脈結紮術を施行した (Fig. 1H). 術後, 右視力障害, 右外転 神経麻疩とも 1 週間以内に消失し, MRIにて動脈瘤内の
血栓化が確認された。

<症例 17 $>22$ 歳, 男性.

右視床梗塞による左不全片麻瘴を呈して入院. 右内頸動 脈BTO下での slow injection angiography (Fig. 2A-D)にて, $\mathrm{C} 3$ から $\mathrm{C} 4$ 部におよぶ $30 \mathrm{~mm}$ 径で不整形の巨大動脈瘤が描 出された。この方法は, 症例 16 における aneurysmographyと同様，動脈瘤の neck, domeの描出に有用であった。 本症例では BTO 時に神経脱落症状はみられなかったが, BTO 下でのSPECTにて右大脳半球に血流低下がみられた ので, 22 歳という年齢を考慮し, 伏在静脈を用いて右外 頸動脈起始部と M2 吻合(high flow bypass) し, 内頸動脈 結紮術を施行した(Fig. 2E, F)。術後の経過は良好であった。

\section{$<$ 症例 24 > 52歳, 女性.}

右外転神経麻痺で発症. 脳血管撮影で右の海綿静脈洞内 に28 mm径の巨大動脈瘤を認めたが, 通常の脳血管撮影 ではneck と domeの位置が十分に把握できなかった(Fig. 3A，B). しかし, slow injection angiographyを行うことに よってneckがC3 部にあることがわかり(Fig. 3C-F)，直接 クリッピング術を施行した(Fig. 3G，H). 術前の外転神経 麻瘏は消失し, 術後の経過は良好であった。 

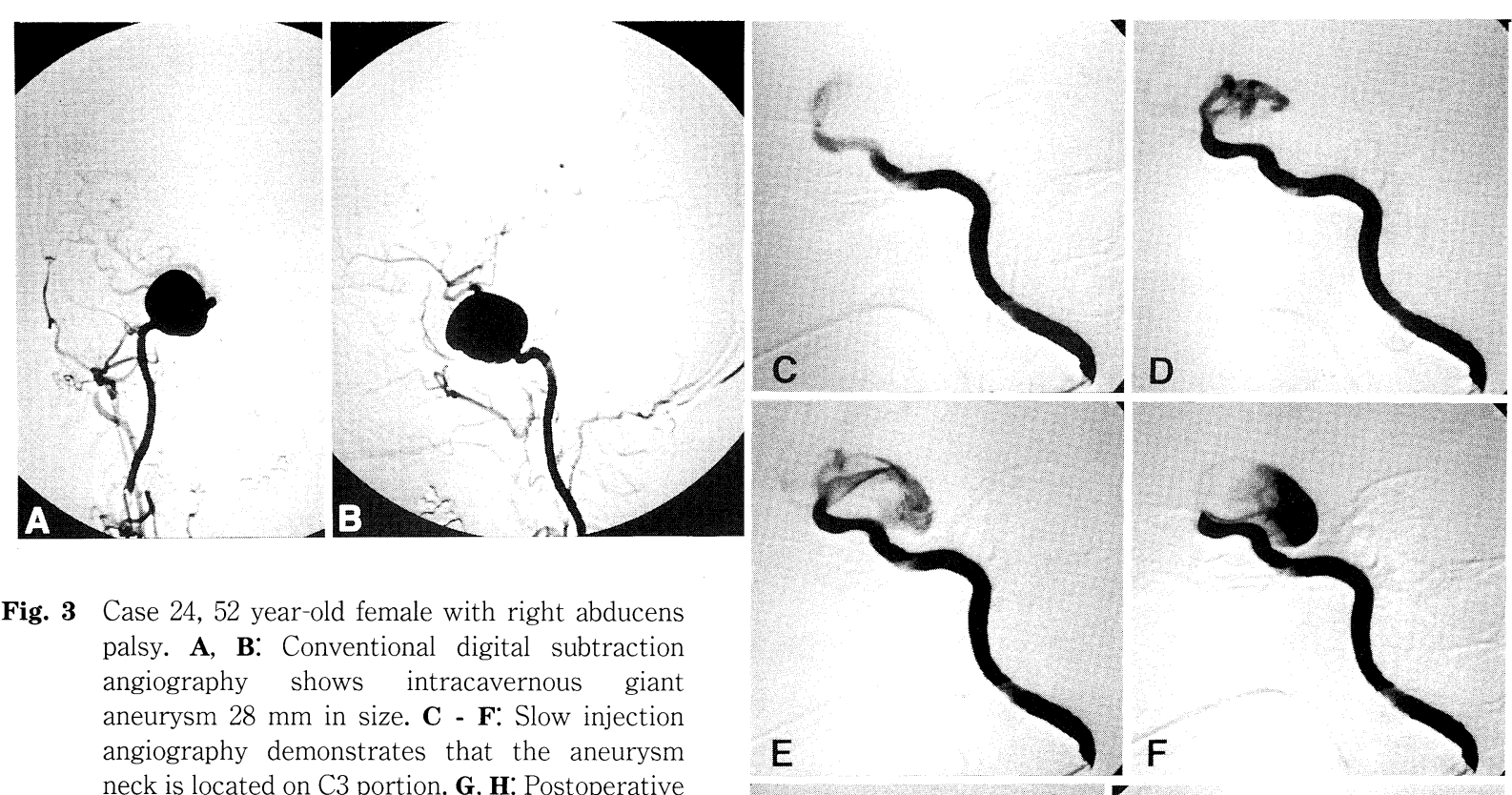

Fig. 3 Case 24, 52 year-old female with right abducens palsy. A, B: Conventional digital subtraction angiography shows intracavernous giant aneurysm $28 \mathrm{~mm}$ in size. C - F: Slow injection angiography demonstrates that the aneurysm neck is located on C3 portion. G, H: Postoperative angiogram shows that the giant aneurysm was completely clipped.

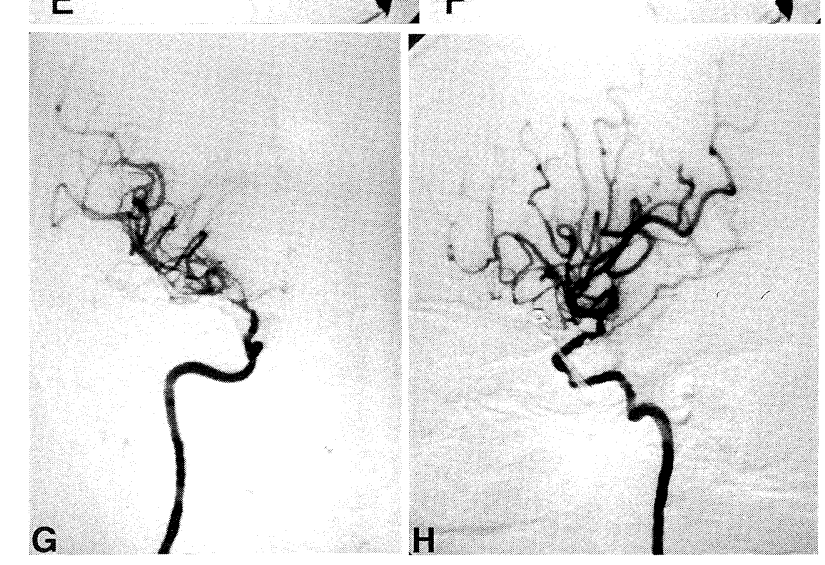

考察

海綿静脈洞部動脈瘤は内頸動脈から発生する動脈瘤全体 の約 $10 \sim 15 \%$ 占め, 女性に多く, 約 $10 \%$ の症例で両側 性に存在する ${ }^{17)}$.

海綿静脈洞部動脈瘤については，その自然経過が一般に 良好とされているところから ${ }^{13)}$ ，手術適応に関して議論 も多い. 部位的には, 動脈瘤の一部がクモ膜下腔に伸展す るもの，あるいは内頸動脈の anterior siphon（C3）部から 発生するものについて外科的適応があるとする意見がある 14)。また，症候性の同部の動脈瘤については，進行性の眼 球運動障害, 視力・視野障害, 同側の顔面痛・眼窩部痛を 訴えるものについて手術適応があると報告されている ${ }^{13)}$ 14).しかし，これまでの報告には無症候性のものや $10 \mathrm{~mm}$ 以下の小動脈瘤を含めて分析が行われており ${ }^{16)}$ ，この部 の動脈瘤で症候性の巨大動脈瘤だけを集めて分析したもの は報告されていない，本研究において我々は，これまでに
経験した内頸動脈海綿静脈洞部動脈瘤のうち, 巨大動脈瘤 で症候性のものを 24 例まとめ, 術前のデータに基づき適 切な治療を行うことにより良好な予後が得られることを明 らかにした。

この部位の動脈瘤については，何らかの形で外科的治療 が加えられている症例の報告が多く, 未治療のまま自然経 過を観察している報告はわずかである 11)13115)16)18).このう ち, 未治療のまま経過観察中にクモ膜下出血を起こした症 例は 2 例報告されており注目に值する ${ }^{13) 18)}$. 未治療例にお ける神経症状の変化については, Kupersmithら ${ }^{13)}$ は34例 の経過観察例のうち2例に神経症状の悪化を認め, Linskey ${ }^{18)}$ は20例のうち7例に神経症状の悪化を認めた と報告している. 我々の症例 1 から 4 は, 種々の理由で未 治療のまま経過観察をしている症例であるが(Table 1), 4 年から 10 年の経過観察中, 神経症状が悪化したり, 画像 上動脈瘤が明らかに大きくなったという症例はなかった。 生命予後という観点からは, この部の動脈瘤の予後は良好 
であるが，眼球運動障害や三叉神経領域の疼痛を呈する症 例では外科的治療を考慮する必要があると考えられる.

従来よりこの部の動脈瘤に対しては種々の外科的治療法 が試みられてきた。総頸動脈ないし内頸動脈の結紮術は最 も古くから行われてきた方法である 6) 20) 26). Nishioka ら ${ }^{20}$ は虚血性合併症の頻度について内頸動脈結紮術では $49 \%$, 総頸動脈結紮術では $28 \%$ あ゙あたとし, Kakら ${ }^{12)}$ は内頸 動脈結禁術では $40 \%$, 総頸動脈結紮術では $14 \%$ の頻度で あったと報告している. Mountら ${ }^{19)}$ は総頸動脈結紮術の 方がより安全に施行できるが, 内頸動脈結紮術の方が動脈 瘤の血栓化は早期に達成されるとしている。しかし, 総頸 動脈結㮃術と内頸動脈結㮃術との間で, 動脈瘤の血栓化の 達成される確率や動脈瘤の大きさの減少度に差がないとす る報告も多い ${ }^{9121}{ }^{23)}$. 総頸動脈結紮術の際は外頸動脈と内 頸動脈との間の交通が残存し，そのため内頸動脈内の clot による thromboembolismなどの合併症が内頸動脈結紮術 より低いのではないか，と考えられている ${ }^{26)}$. 我々の症 例では，総頸動脈結紮術を 7 例，内頸動脈結紮術を 2 例に 施行しているが(Table 1 症例 5 から 13), す心゙て 10 年以上 前の症例ばかりである。1 例(症例 9)を除いて術後神経症 状の改善がみられ，総頸ないし内頸動脈結㮃術のみでも本 動脈瘤の治療が可能であることを示している。しかし, 症 例 11 において手術 5 年後に遊離血栓によると思われる脳 梗塞をおこしていることは, 総頸ないし内頸動脈結紮術で の遅発性虚血性合併症に注意が必要であることを示してい る. 実際, 総頸ないし内頸動脈結紮術後の遅発性の虚血性

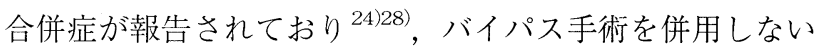
総頸ないし内頸動脈結紮術が行われる機会は減少してきて いる. 我々も最近の症例では，何らかの形でバイパス術を 併用するようにしている。

マイクロサージャリーの発達, BTOを併用したSPECT などで術前に脳血流予備能が検索できるようになったこと などの理由で, 海綿静脈洞部動脈瘤の外科治療は, STAMCA anastomosisないし EC-M2 high flow bypassを併用 した内頸動脈結紮術 (あるいは血管内手術による内頸動脈 閉塞術)が主に行われるようになっている2)-4)810)25). 通 常，BTOあるいはSPECT with BTOを術前に行い，脳血 流予備能のあるlow riskの患者にはSTA-MCA anastomosisを，脳血流予備能の少ない high riskの患者には high flow bypass を併用することが多い2). 我々は，これらの脳 血流予備能の評価に加えて，より若い患者では極力 high flow bypass を併用するようにしている(Table 1, Fig. 4). 症例 14 から 22 は, 内頸動脈結紮術に加えてバイパス手術 を行った症例であるが，術後ほとんどの症例で早期に神経 症状の改善がみられ，不全片麻痺を生じた 1 例を除いて長 期の予後も良好であった。

Parkinson $~^{22)}$, Dolenc ら ${ }^{5)}$ の先駆的な研究により, 海 綿静脈洞の解剖が次第に明らかになり，この部の動脈瘤に 対しても直接クリッピングが試みられるようになってきた 1) 7). 我々は, 海綿静脈洞部巨大動脈瘤のうち，その neck がanterior siphon（C3）にあるものに対しては直接クリッ ピングを行っている。この部の巨大動脈瘤では，頸部内頸

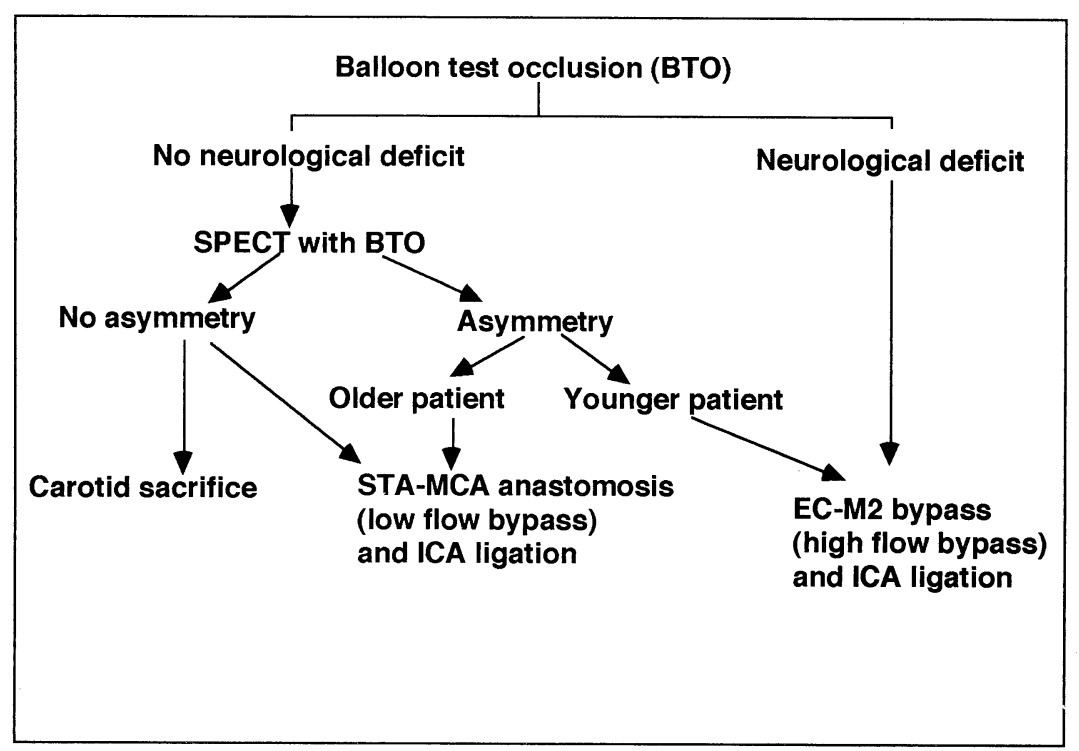

Fig. 4 Our current treatment protocol for management of intracavernous giant aneurysms. Direct clipping is applied in an aneurysm whose neck is located on the anterior siphon (C3) of the internal carotid artery. 
動脈と動脈瘤の遠位部で内頸動脈をトラップし, trapping-evacuation technique ${ }^{27)}$ を用いて動脈瘤の十分な減圧 をはかり，さらに動脈瘤を開放して，その orificeを動脈 瘤の内外から観察し, 内頸動脈を形成するようにクリッピ ングを施行する必要がある。このような方法により外科治 療を行った我々の 2 症例はともに良好な予後であったが (Table 1 症例 23 と 24), 術前行ったBTO下での slow injection angiography あるいは aneurysmographyが, 動脈瘤の neck, domeの位置, 大きさ, 方向などの判断に非常に有 用であり，直接クリッピングを試みようとする際は必須の 術前検査であるといえる。

現時点での我々の海綿静脈洞部巨大動脈瘤の治療方針に ついてFig. 4に示した. まず, BTOを30分行い, 神経学 的脱落症状を呈するものには, high flow bypass と内頸動 脈結紮術を行う. 神経学的脱落症状の出現しないものに対 しては, BTO下にSPECTを行い, asymmetryが明らかで, より若い患者には high flow bypassと内頸動脈結紮術を, より高齢の患者にはSTA-MCA anastomosis と内頸動脈結 紮術を行う。しかし，どのくらいの年齢を基準に若年と高 齢をわけて考えようとするのか, あるいはBTOにdiamox や低血圧を負荷したときのデータを restingの状態と比較 して high flow bypass と low flow bypassの適応を考えてい くなど, 今後検討すべき課題は多い. BTO下でのSPECT でasymmetryのないものに対してはSTA-MCA anastomosis と内頸動脈結紮術か, 総頸ないし内頸動脈の結紮術の みを行う。また, 直接クリッピング術は, anterior siphon (C3)に neckのあるものに対して, BTO, slow injection angiography, aneurysmographyなどの結果を総合的に判 断し，適応を決めている。

以上，これまで我々の経験した 24 例の海綿静脈洞部巨 大動脈瘤症例をまとめ, その治療方針, 治療結果について 報告し, 文献的考察を加えた。近年発達した種々の診断技 術を駆使し, それを総合的に判断し, 適切な外科的治療を 施行することにより，この部位の巨大動脈瘤については良 好な予後が期待できると考えられる.

\section{文献}

1) Al-Rodhan NRF, Piepgras DG, Sundt TMJ: Transitional cavernous aneurysms of the internal carotid artery. Neurosurgery 33: 993-998, 1993

2) Barnett DW, Barrow DL, Joseph GJ: Combined extracranialintracranial bypass and intraoperative balloon occlusion for the treatment of intracavernous and proximal carotid artery aneurysms. Neurosurgery 35: 92-97, 1994

3) Diaz FG, Ausman JI, Pearce JE: Ischemic complications after combined internal carotid artery occlusion and extracranial-intracranial anastomosis. Neurosurgery 10: 563 $-570,1982$

4) Diaz FG, Ohaegbulam S, Dujovny M, et al: Surgical man- agement of aneurysms in the cavernous sinus. Acta Neurochir (Wien) 91: 25-28, 1988

5 ) Dolenc V: Direct microsurgical repair of intracavernous vascular lesions. J Neurosurg 58: 824-831, 1983

6) Faria MJ, Fleischer AS, Spector RH: Bilateral giant intracavernous carotid aneurysms treated by bilateral carotid ligation. Surg Neurol 14: 207-210, 1980

7 ) Fukushima T, Day J, Tung H: Intracavernous carotid aneurysms. In: Apuzzo MLJ (ed), Brain Surgery, Churchill Livingstone, New York, 1992, pp 925-944

8 ) Gelber BR, Sundt TJ: Treatment of intracavernous and giant carotid aneurysms by combined internal carotid ligation and extra- to intracranial bypass. J Neurosurg 52: 1-10, 1980

9) Giannotta SL, McGillicuddy JE, Kindt GW: Gradual carotid artery occlusion in the treatment of inaccessible internal carotid artery aneurysms. Neurosurgery 5: 417-421, 1979

10) Heros RC, Nelson PB, Ojemann RG, et al: Large and giant paraclinoid aneurysms: surgical techniques, complications, and results. Neurosurgery 12: 153-163, 1983

11) Inagawa T: Follow-up study of unruptured aneurysms arising from the $\mathrm{C} 3$ and $\mathrm{C} 4$ segments of the internal carotid artery. Surg Neurol 36: 99-105, 1991

12) Kak VK, Taylor AR, Gordon DS: Proximal carotid ligation for internal carotid aneurysms. A long-term follow-up study. J Neurosurg 39: 503-513, 1973

13) Kupersmith MJ, Hurst R, Berenstein A, et al: The benign course of cavernous carotid artery aneurysms. J Neurosurg 77: 690-693, 1992

14) Linskey ME, Sekhar LN, Hirsch WJ, et al: Aneurysms of the intracavernous carotid artery: Clinical presentation, radiographic features, and pathogenesis. Neurosurgery 26: 71 79, 1990

15) Linskey ME, Sekhar LN, Hirsch WJ, et al: Aneurysms of the intracavernous carotid artery: Natural history and indications for treatment. Neurosurgery 26: 933-937, 1990

16) Linskey ME, Sekhar LN, Horton JA, et al: Aneurysms of the intracavernous carotid artery: A multidisciplinary approach to treatment. J Neurosurg 75: 525-534, 1991

17) Locksley HB: Natural history of subarachnoid hemorrhage, intracranial aneurysms and arteriovenous malformations. Based on 6368 cases in the cooperative study. J Neurosurg 25: $219-239,1966$

18) Lye RH, Jha AN: Unruptured aneurysms of the intracavernous internal carotid artery: Outcome following carotid ligation or conservative treatment. Br J Neurosurg 3: 181188, 1989

19) Mount LA: Results of treatment of intracranial aneurysms using the Selverstone clamp. J Neurosurg 25: 660-682, 1959

20) Nishioka H: Report on the cooperative study of intracranial aneurysms and subarachnoid hemorrhage. Section VII. I. Evaluation of the conservative management of ruptured intracranial aneurysms. J Neurosurg 25: 574-592, 1966

21) Odom GL, Tindall GT: Carotid ligation in the treatment of certain intracranial aneurysms. Clin Neurosurg 15: 101-116, 1968

22) Parkinson D: A surgical approach to the cavernous portion of the carotid artery: Anatomical studies and case report. J Neurosurg 23: 474-483, 1965

23) Pozzati E, Fagioli L, Servadei F, et al: Effect of common carotid ligation on giant aneurysms of the internal carotid artery: Computerized tomography study. J Neurosurg 55: 527-531, 1981 
24) Roski RA, Spetzler RF, Nulsen FE: Late complications of carotid ligation in the treatment of intracranial aneurysms. J Neurosurg 54: 583-587, 1981

25) Silvani V, Rainoldi F, Gaetani P, et al: Combined STA/MCA arterial bypass and gradual internal carotid artery occlusion for treatment of intracavernous and giant carotid artery aneurysms. Acta Neurochir (Wien) 78: 142-147, 1985

26) Swearingen B, Heros RC: Common carotid occlusion for unclippable carotid aneurysms: An old but still effective operation. Neurosurgery 21: 288-295, 1987

27) Tamaki N, Kim S, Ehara K, et al: Giant carotid-ophthalmic artery aneurysms: Direct clipping utilizing the "trappingevacuation" technique. J Neurosurg 74: 567-572, 1991

28) Winn HR, Richardson AE, Jane JA: Late morbidity and mortality of common carotid ligation for posterior communicating aneurysms. A comparison to conservative treatment. J Neurosurg 47: 727-736, 1977 